\title{
KSIĄŻKA O CZESKIM ROKU 1968
}

Urszula Kowalska, ,,Tato noc nebude krátka...”. Doświadczenie roku 1968 w czeskiej literaturze emigracyjnej, Poznań: Wydawnictwo Naukowe UAM, 2015, 346 s.

Tytuł książki Urszuli Kowalskiej „Tato noc nebude krátka...” Doświadczenie roku 1968 w czeskiej literaturze emigracyjnej, zapowiada próbę szerokiego opisu recepcji Praskiej Wiosny roku 1968 w czeskiej literaturze emigracyjnej. Próbę tę należy uznać, wyprzedzając wszelkie, rodzące się podczas lektury tekstu, uwagi polemiczne, ze wszech miar za udaną. Problem roku 1968 sprowokował polską badaczkę, podobnie jak wielu badaczy czeskich, reprezentujących różne dziedziny nauki (historyków, socjologów, antropologów kultury, psychologów społecznych, politologów, literaturoznawców) do zmierzenia się z opisem tego fenomenu. Jest to problematyka podejmowana zarówno w Czechach, jak i w Polsce, od pewnego już czasu — posiada ona bogatą i poważną literaturę. Na wstępie należy przypomnieć, że w Czechach odbyło się parę konferencji, podczas których zaproszeni naukowcy, eksperci i autorytety z kraju oraz z zagranicy, prezentowali swoje badania na temat emigracji i literatury emigracyjnej. W wyniku tych spotkań powstało kilka obszernych zbiorów, zawierających ciekawe materiały pokonferencyjne, chociażby Česká a polská emigračni literatura: sbornik z mezinárodni vĕdecké konference (Opava 2002); Emigrace a exil jako zpưsob života: II sympozium o českém vystěhovalectví, exulantství a vztazich zahraničnich Čechi̊ $k$ domovu (Praha 2001); Literatura, vězení, exil (Praha 1997). Zostały one odnotowane także w monografii Urszuli Kowalskiej. Dyskusja o Praskiej Wiośnie i emigracji trwa i będzie trwać tak długo jak rozliczanie się z totalitarną przeszłością w Czechach i w całej Europie Środkowej. Kwestia legendarnego już roku 1968 w krajach tej części Europy, i nie tylko, to moment zwrotny także w najnowszej historii Zachodu, pozostaje nadal bardzo żywa. Zagadnienie dotyka dużego obszaru geopolitycznego — od USA, przez Włochy, Francję, Niemcy, do Czechosłowacji i Jugosławii. O znaczeniu roku 1968 w naszej historii i kulturze pytały m.in. Hanna Wróblewska i Maria Brewińska, współredaktorki pracy zbiorowej Rewolucje 1968 (Warszawa 2008). Znane są opracowania naukowe Jerzego Eislera czy Piotra Osęki, mówiące o historii politycznej roku 1968. Mamy przekład tomu Maj '68. Rewolta pod redakcją Daniela Cohn-Bendita i Rüdigera Dammanna o niemieckim roku 1968, wydany przez Krytykę Polityczną czy 
numer tego pisma sprzed kilku lat o paryskim Maju. Pracownicy Instytutu Pamięci Narodowej w swoich pracach badawczych i edukacyjnych podejmowali temat trudny i kontrowersyjny, czyli udział PRL w agresji na Czechosłowację. Warto tutaj zwrócić uwagę na materiały z czesko-polskiej konferencji naukowej Wokół Praskiej Wiosny. Polska i Czechosłowacja w 1968 roku (Warszawa 2004), pod redakcją Łukasza Kamińskiego. Autorzy tych prac wyraźnie podkreślają, że rok 1968 był wielką cezurą pod wieloma względami, głównie kulturowymi czy społecznymi, co jest prawdą. Do dziś odczuwamy tego konsekwencje. Bez analizy zjawisk związanych z ruchem, który miał u swych podstaw wyzwolić człowieka, nie zrozumiemy także naszej, późno nowoczesnej tożsamości.

Rok 1968 jako źródło inspiracji artystów młodszego pokolenia stanowi jeden z tematów innego krytycznego ujęcia zagadnienia czeskiej literatury emigracyjnej na gruncie polskim. Tego wyzwania podjęła się w 2006 roku opolska badaczka Joanna Czaplińska w książce Tożsamość banity. Problematyka autoidentyfikacji w młodej czeskiej prozie emigracyjnej po roku 1968. Jej pierwsza monografia, która wyszła w języku czeskim Přidaná hodnota exilu. Úvahy o české exilové literatuře po roce 1968 (Praga 2014), poświęcona jest również tym zagadnieniom i stanowi swoistą kontynuację oraz nawiązanie do polskiego wydania. Sam temat roku 1968 był już podejmowany m.in. przez Andrzeja Krawczyka w jego tekstach „Normalizacja” po czesku (Warszawa 1982) czy Praska wiosna 1968 (Warszawa 1998). Potrzeba analizy tego zjawiska u polskich badaczy wynika z faktu, że niewielu Polaków zdawało sobie wówczas sprawę (i nadal zdaje z tego), że zniewolenie społeczeństwa czeskiego i jego kontrola po 1968 roku osiągnęły znacznie większe rozmiary niż w Polsce. W Czechosłowacji miały miejsce tysiące aresztowań, tysiące ludzi zmuszono do emigracji i pozbawiono obywatelstwa. Należy jednak przyznać, że znaczna część społeczeństwa polskiego przyjęła interwencję wojsk Układu Warszawskiego z oburzeniem. Wyrazem protestu stały się liczne akty sprzeciwu. Najtragiczniejszym przejawem było samospalenie Ryszarda Siwca, dokonane 8 września 1968 roku na Stadionie X-lecia w Warszawie. Dla nas, Polaków, zawsze będzie bolesnym wspomnieniem, że w 1968 roku żołnierz polski był w Czechosłowacji okupantem.

W czeskiej kulturze często spotykamy się z nostalgicznym spojrzeniem, przypominającym słodko-gorzką młodość, przypadającą na tzw. złote lata 60. XX wieku i demitologizującym ten okres. Należy tutaj przypomnieć, że w tym czasie powstał swoisty ferment w kulturze czeskiej. Oczywiście powinno się traktować ten moment dosyć umownie, bo największe dokonania, chociażby znanych czeskich pisarzy, jak Milana Kundery, Bohumila Hrabala czy Josefa Škvoreckiego, których twórczość odczytuje Urszula Kowalska, przypadają na lata późniejsze. Praska Wiosna to był krótki okres politycznej liberalizacji w Czechosłowacji, trwającej od 5 stycznia do momentu, gdy ZSRR i inni członkowie Układu Warszawskiego (Polska, Węgry, NRD i Bułgaria) dokonali inwazji w nocy 20 sierpnia na 21 sierpnia 1968 roku. Mimo to mamy tu do czynienia jednak z pewnym pokoleniem, które dostrzegło, że ideologia komunistyczna coraz bardziej nie przystaje do zmian społecznych — bujnego rozwoju życia kulturalnego, zwłaszcza nowego kina czeskiego i importowanych z Zachodu nowych prądów w kulturze młodzieżowej (muzyki bigbitowej, ruchu hippisowskiego itp.). W latach 70. u naszych południowych sąsiadów obowiązywał polityczny kurs tzw. normalizacji jako skutek wydarzeń sierpnia 1968, czyli stopniowe odchodzenie od reform Praskiej Wiosny. Dla literatury oznaczało to powrót do socrealizmu; wartość dzieła literackiego mierzono poziomem zaangażowania społeczno-politycznego, oczywiście po stronie właściwej pod względem ideologicznym. W coraz większej opozycji do rządu pozo- 
stawali pisarze. Czechosłowacka Nowa Fala w kulturze została wówczas bezwzględnie uśmiercona i tylko niektóre ze zjawisk były kontynuowane za granicą.

Urszula Kowalska w swojej monografii przywołuje znamienne spostrzeżenie czeskiego historyka, thumacza i filozofa Jana Pauera, który, analizując rok 1968 konstatuje: „Praska Wiosna nie zmieniła świata, ale zmieniła spojrzenie na świat” (s. 8). Polska badaczka polem swego zainteresowania nie czyni jedynie ponownego odkrywania i analizowania zjawiska emigracji i literatury emigracyjnej. Książka Kowalskiej przynosi analizę aspektów literatury emigracyjnej dotąd podejmowanych lub opisywanych jedynie szczątkowo. Przedmiotem głównych peregrynacji naukowych staje się dla niej próba zobiektywizowania licznych koncepcji, dotyczących miejsca przemian lat 60 . w czeskiej historii. Autorka określa swoje zadanie wprost:

Refleksję interpretacyjną uzupełnia publicystyka dotycząca znaczenia roku 1968, kontekst czeskiej historii i tradycji literackiej oraz fragmenty tekstów znanych i cenionych na świecie pisarzy czeskich. Parafrazując słowa Ryszarda Nycza, dzieła Škvoreckiego, Kundery i Kohouta stały się tropem rzeczywistości. Równie ważne pozostają konteksty kulturowe i literackie, które odgrywają określoną rolę w opisie wydarzeń i doświadczeń związanych z inwazją (s.14).

Wśród wielu opracowań (indywidualnych i zbiorowych) monografia Urszuli Kowalskiej jawi się — przynajmniej na gruncie polskim — jako ciekawy przykład przybliżenia naszemu odbiorcy nieznanego mu bliżej obszaru czeskich kulturowych eksploracji doświadczenia granicznego, jakim był rok 1968. Podobnie szeroka monografia nie powstała dotąd zresztą również na gruncie czeskim, co oczywiście wzmacnia rangę publikacji. W świetle tych uwag wypada stwierdzić, że monografia „Tato noc nebude krátka..." Doświadczenie roku 1968 w czeskiej literaturze emigracyjnej stanowi jak na razie najobszerniejsze i najwszechstronniejsze opracowanie na ten temat $\mathrm{w}$ polskim środowisku bohemistycznym. Nie zmienia tego faktu ukazanie się już wcześniej przed wydaniem pracy Kowalskiej książek poświęconych bądź samej problematyce roku 1968 w Czechosłowacji, bądź czeskiej literaturze emigracyjnej. Autorka rozprawy zdecydowała się na różnorodne ujęcie tego tematu, podjęła się zadania kompleksowego rozpatrzenia wybranego problemu, śledząc jego losy w twórczości kilku pisarzy. Dzięki temu stworzyła ona publikację, która w sposób krytyczny ukazuje interpretowanie daty 1968 w twórczości szczególnie Pavla Kohouta, Milana Kundery i Josefa Škvoreckiego, którzy wyemigrowali z kraju po inwazji wojsk Układu Warszawskiego na teren Czechosłowacji. Tym, co zwraca szczególną uwagę w omawianej monografii, jest kwestia doboru nazwisk twórców, których losy, sylwetki i praca artystyczna zostały bliżej przedstawione. Należy pamiętać bowiem, że dorobek twórczy wspomnianej trójki artystów stanowi jedynie ułamek zróżnicowanej panoramy tego doświadczenia w czeskiej kulturze. Wystarczy wspomnieć działalność m.in. takich artystów jak: Ludvík Aškenazy, Jaroslava Blažková, Antonín Brousek, Josef Jedlička, Jiří Kolář, Jan Křesadlo,Věra Linhartová, Arnošt Lustig, Ladislav Mňačko czy Peter Repka, o których autorka monografii wzmiankuje, ale nie poświęca ich twórczości wystarczająco dużo uwagi. Bardzo szeroka wykładnia literatury emigracyjnej, patronująca zamieszczonym w książce rozważaniom, zmusza do postawienia pytania, dlaczego w rozprawie tak mało miejsca przeznaczono tym artystom. W istocie bowiem wywód Kowalskiej miał być poświęcony utworom, które uważa za emigracyjne, „,bo powstają na emigracji, są opowieściami o emigracji, pisanymi przez emigrantów, wplecionymi w doświadczenia i zdarzenia nieemigracyjne, odwołującymi się do ponadczasowych wartości i idei charakteryzujących czeską kulturę, historię i literaturę, zarówno przed, jak i po inwazji" (s. 14). Szkoda, że w pracy autorka nie sięgnęła po niepublikowane rękopisy i zapo- 
mnianych autorów, co wydatnie zwiększyłoby wiedzę czytelników na temat czeskiej literatury emigracyjnej i być może rzuciło nowe światło na dotychczasowe badania. Nietrudno dostrzec, że zarzuty, które tu wobec rozprawy Kowalskiej padają, powodowane są niedosytem. Oczywiste jest jednak także, że nie mogła napisać o wszystkim.

Urszula Kowalska poddaje analizie obok tekstów literackich Kundery, Kohouta i Škvoreckiego również prace publicystyczne, reakcje, opinie i oceny roku 1968 innych artystów, na których reżim komunistyczny odcisnął wyraźne piętno, w efekcie stały się one swego rodzaju świadectwem czasów. Autorka książki postanowiła rzucić światło na pojedyncze teksty i działalność wybranych twórców, dzięki temu za indywidualnymi realizacjami odkrywa ogólne prawidłowości rządzące kulturowymi reprezentacjami Praskiej Wiosny i dyskursami ją opisującymi. Wskutek tego podczas lektury opracowania uderza próba zachowania przez Urszulę Kowalską obiektywizmu badawczego, przy równoczesnym przedstawieniu wielości perspektyw i kątów spojrzenia. Autorka żywi przekonanie, że „osobista święta prawda” (s. 304) artysty ma wpływ na sposób percypowania rzeczywistości wśród odbiorców. Praska Wiosna dzięki tej różnorodności jawi się zarówno jako przedmiot literackiej reprezentacji, jak i impuls otwierający nowe perspektywy w dziedzinie postrzegania wydarzeń historycznych. Autorka słusznie zauważa, że „Liczba „1968” funkcjonuje w czeskiej literaturze i publicystyce jako symbol końca i początku — końca epoki praskiej wiosny i początku „normalizacji”, choć te dwa etapy oddzielone są przecież pewnym okresem przejściowym" (s. 15).

Swe poszukiwania badawcze, zmierzające do rekonstrukcji literackiego obrazu roku 1968, Kowalska komponuje, wyznaczając trzy wyraźnie zarysowane kręgi. Pierwszy podejmuje refleksje na temat głośnej inwazji. Drugi stanowi rozważania dotyczące bolesnej normalizacji. Trzeci wreszcie zajmuje się ukontekstowieniem roku $1968 \mathrm{w}$ odniesieniu do czeskiej i europejskiej historii XX wieku, a także stuleci wcześniejszych. Pomocne w tym stają się dla autorki współczesne komentarze publicystów, historyków, dziennikarzy i pisarzy uwzględniające dłuższą perspektywę czasową. Temat rozliczenia z przeszłością podejmuje w rozdziale Dobrý večer... po dvaceti letech. Praska wiosna - spojrzenie z dystansu, który traktuje o obecnym obrazie społeczeństwa czeskiego po dwóch rewolucjach 1968 i 1989 roku. Badaczka nie dąży do zakwestionowania przedstawianych opinii, natomiast proponuje głębsze odczytanie sensów dzieł mających już ustaloną i popartą badawczymi autorytetami wykładnię. Przypomina, że rok 1989 ,żywi” się mitem Praskiej Wiosny. W rozdziale czytamy:

Porażka przeradza się w sukces. Jak istotne wydają się w roku 1989 nawiązania do roku 1968 udowadnia nawet magia cyfr — odwrócona liczba 68 to 89. Swoiście wykorzystywane bywa poszukiwanie historycznych asocjacji. Sprzyja temu pokoleniowa analiza minionych wydarzeń, szczególnie rozpowszechniona wśród przedstawicieli generacji naznaczonej inwazją i dążącej do przemian roku 1989 (s. 277).

W sferze badawczej publikacja z powodzeniem realizuje zasygnalizowany przez autorkę postulat poszerzania stanu istniejącej wiedzy przy jednoczesnym zachowaniu dotychczasowych ocen dorobku poszczególnych pisarzy. Urszula Kowalska zaznacza, że:

Dzieła przedstawicieli czeskiej emigracji posierpniowej, starszej generacji - Josefa Škvoreckiego (1924-2012), Milana Kundery (ur. 1929) oraz Pavla Kohouta (ur. 1928) - stanowią egzemplifikację kulturowych refleksji i pamięci o motywach „sierpniowych", związanych z nimi znaczeniach, emocjach, jak również literackich sposobach ich kreowania. [...] Doświadczenie środkowoeuropejskiej skomplikowanej historii, naznaczonej totalitaryzmami jest stałym motywem ich twórczości literackiej i publicystycznej, różnie ocenianej w kraju, jak i za granicą. Powieści Škvoreckiego, Kundery 
i Kohouta wskazują na symetryczną zależność, w pewnym sensie symbolizującą sytuację emigranta, pamiętającego o rzeczywistości krajowej, dryfującego we wspomnieniach, literaturze, publicystyce, pracy naukowej i codziennym życiu między ojczyzną a obczyzną (s. 11-13).

Autorka pieczołowicie zadbała o to, aby w pracy zostały przywołane kanoniczne już publikacje tych autorów, którzy mieli znaczący udział w kreowaniu wizerunku Czechów za granicą. Urszula Kowalska, powołując się na liczne pozycje politologiczne, socjologiczne czy kulturoznawcze, umiejętnie udowadnia, jak to jednostkowe i kolektywne doświadczenie graniczne, zdolne było do zredefiniowania tożsamościowych autodefinicji. Autorka książkę ,,Tato noc nebude krátka...” Doświadczenie roku 1968 $w$ czeskiej literaturze emigracyjnej dzieli na sześć rozdziałów, które pokrywają się z dokonanym przez nią sposobem problematyzacji zjawiska od „karnawału, przez nadzieję, iluzję, zwątpienie, niewiarę, po marzenie i mit” (s. 5). Książka składa się z dwóch zasadniczych części — pierwszą stanowią trzy rozdziały (152 strony), w których przedstawiony został interesujący autorkę rok 1968, jego znaczenie i miejsce w czeskiej świadomości historycznej oraz kulturowej jako przeżycie pokoleniowe, podjęty został temat doświadczenia emigracji narodu czeskiego, problem asymilacji, charakterystyka emigracyjnych środowisk, kwestia pamięci historycznej, kulturowej, zbiorowej czy indywidualnej pamięci emigranta, drugą zaś zasadniczą otwiera rozdział Postavy mého románu jsou moje vlastní možnosti, které se neuskutečnily. O sztuce powieści emigracyjnej, poruszający kwestię specyficznej sytuacji pisarza przebywającego na emigracji, wątek uchodźstwa, podejmowanych przez autorów decyzji i strategii pisarskich, jak zmiana języka i znaczenie języka ojczystego, relacje między emigracją a ojczyzną. Główny cel badawczy postulowany w tytule monografii podlega realizacji w rozdziale Rozume pochop a nevyteč z lebky... Reprezentacja roku $1968 \mathrm{w}$ czeskiej literaturze emigracyjnej, w którym Kowalska wskazuje na podstawie lektury tekstów Škvoreckiego, Kohouta oraz Kundery niektóre powtarzalne motywy i wątki, sugerujące pewne stałe sposoby postrzegania roku $1968 \mathrm{w}$ nawiązaniu do historycznych wydarzeń, stereotypów i wartości. Znaczenia tej drugiej części przecenić nie sposób - staje się cenną pomocą dla osób zainteresowanych twórczością i dokonaniami zarówno konkretnych autorów, jak i — a taka sytuacja ma miejsce w tym wypadku — pewnego ,środowiska”, osób połączonych wspólnymi pokoleniowymi przeżyciami.

Liczne przywołane w monografii teksty jak eseje, rozprawy historyczne, wywiady, które obrazują czy opisują wydarzenia istotne $\mathrm{z}$ punktu widzenia polityki, historii, życia społeczno-obyczajowego, wskazują z jednej strony na jej rozpiętość tematyczną, z drugiej niestety czasami jedynie pośrednio dotyczą życia kulturalno-literackiego. Wydaje się jednak, że mimo solidności zgromadzenia i rekapitulacji opinii znawców przedmiotu (szczególnie w pierwszych rozdziałach monografii) autorka zbyt wiele uwagi poświęciła na te rozważania wstępne, które zdominowały refleksję dotyczącą poetyki samej literatury emigracyjnej. Kowalskiej nie udało się uniknąć mówienia o rzeczach szeroko znanych i omawianych.

Dla polskiego odbiorcy recenzowanej monografii szczególnie interesująca wydać się może odmienność wartościowania i pamięci, różnicująca postrzeganie Praskiej Wiosny w Polsce i w Czechach. Dzięki jej lekturze polski czytelnik odkrywa przede wszystkim, że Praska Wiosna stała się w kulturowej refleksji naszych południowych sąsiadów przedmiotem literackiego modelowania. Kultura czeska bardzo intensywnie i ekstensywnie zareagowała na ten kataklizm, powracając do niego w licznych tekstach, wpisujących się w heterogeniczne poetyki. Monografia Kowalskiej jest próbą 
stworzenia koherentnej całości obrazującej rozpoznania sposobów reprezentacji Praskiej Wiosny w czeskiej literaturze emigracyjnej. Na polskim rynku nie było dotychczas publikacji, która $\mathrm{w}$ równie szeroki, a zarazem przystępny sposób ukazywałaby problem „czeskiego roku 1968” w jego rozmaitych aspektach: teoretyczno-filozoficznym, społeczno-obyczajowym, wreszcie w wymiarze egzystencjalnego doświadczenia jednostki. Książka autorstwa Urszuli Kowalskiej znacząco poszerza polski stan badań nad czeską literaturą emigracji i mechanizmami rządzącymi obrazowaniem wydarzeń roku 1968 w kulturze czeskiej — w tym należy dostrzegać jej wartość. Należy tu zauważyć, że wypełnia też lukę w czeskim literaturoznawstwie, w którym do tej pory nie ukazała się pełna monografia, poświęcona literaturze emigracyjnej, chociaż w ostatnim czasie pojawiło się wiele istotnych publikacji, dotyczących tego tematu. Pozycja jest także ciekawa pod względem edytorskim, bowiem została dodatkowo wzbogacona o cenne fotografie ze zbiorów praskiego Archiwum Narodowego (Národní archiv). W swoich badaniach autorka dokonuje analizy tekstów na różnych poziomach, co sprawia, że publikację ,, Tato noc nebude krátka... ” Doświadczenie roku 1968 w czeskiej literaturze emigracyjnej uznać trzeba za rzeczywiście interesującą. Z perspektywy poznawczej monografia stanowi istotne źródło wiedzy o jednym z najbardziej symptomatycznych zjawisk dwudziestowiecznej literatury. Książka Kowalskiej może służyć za pracę źródłową zarówno historykom emigracji jak też historykom literatury czeskiej. Dla Urszuli Kowalskiej badania stanowią pretekst do podjęcia polemiki z czeskim publicystą emigracyjnym Antonínem J. Liehmem, który w wywiadzie z Aleksandrem Kaczorowskim stwierdził, że „Praską Wiosnę usunięto z czeskiej pamięci zbiorowej” (s.16) oraz snucia rozważań na tematy uniwersalne o swoistej ciągłości i cykliczności historii. Zdaniem autorki monografii, czeska kultura nastawiona była i jest na diagnozę spowodowanego przez rok 1968 rozkładu przestrzeni aksjologicznej, skutkującej demontażem wcześniej „obowiązujących” form i norm kulturowych. Tym samym otwiera — jak sądzę — perspektywę dalszych badań i szerszych rozważań.

Dorota Żygadło-Czopnik (Uniwersytet Wrocławski) 